\title{
3 Historical paths to shared interest in quality assurance and evaluation
}

\author{
Olli Suominen, Vera Gorodski Centeno, \\ Galina Gurova, Johanna Kallo, and Xingguo Zhou
}

\section{Introduction}

This chapter explores and outlines the historical background of understanding the development of quality assurance and evaluation (QAE) policies in Brazil, China, and Russia and thus also prepares the ground for the problematics the subsequent chapters analyse. In doing this, we build largely on the previous research literature, albeit occasionally supplementing our analysis with primary documents, such as media reports, policy documents, and parallels found in our interview material. As the following chapters elucidate, although at the level of practical implementation, the countries' experience differs markedly, at the level of political projects and rhetoric (see Chapter 6), they share a growing interest in QAE. In building the case for future chapters, our foremost task is therefore to ask how these three countries, which until recently developed separately, came to share quite similar domestic expectations and interest in QAE. Drawing on politico-socio-historical approaches, we outline the historical trajectories and antecedents of QAE policies in each national context. Our ambition to trace the socio-historical roots of the phenomenon at hand also resonates with the book's broader framework, as uncovering the political situation is one of the three analytical dimensions of the CADEP framework the preceding chapter introduced.

More concretely, we approach our topic by presenting three case-by-case chronological narratives. As QAE policies are linked to some of the megatrends of the latter half of the twentieth century, which has seen growing possibilities of transnational data flows and an increasing emphasis on economic efficiency in public services, the focus of our analysis will be on post-World War II developments. This historical analysis will extend to the present and the challenges the countries are facing. We summarise this analysis with an integrative summary in which we draw together some similarities and differences in the developmental paths towards the countries' shared interest in QAE. As a postscript, we conclude our work with an examination of signs that the three countries are increasingly engaging with the international community and with each other, especially in matters related to education, suggesting possible future research avenues. 


\section{Path dependency and contingent conjectures}

Chapters 1 and 2 discussed the importance of understanding the path dependencies deriving from our ontological presuppositions concerning complexity and, more closely, how the political situation is analysed as a constellation of actors in a specific socio-historical context. In this chapter, with our focus on processual perspectives in tracing the historical paths leading to the introduction of modern QAE policies, we build theoretically on the notion of path dependency, which essentially asserts that present and future choices are made within the constraints set by past choices (O'Sullivan et al. 2006). In the broadest sense, path dependency refers to the very vague notion that "history matters" (Pierson 2000a; Mahoney 2000), but our aim is to go deeper by operationalising the term to show how history matters. Although the concept is used in various ways in different research traditions, all path-dependency perspectives stress several relevant arguments which help us to understand the broader context of developments, such as the interconnectedness of events and the relevance of timing, showing that important developments are frequently the outcome of the earlier breaking points resulting from particular conjunctures (Baumgartner \& Jones 2009; Capano 2009).

All path-dependency perspectives also share an interest in contingent events, which in turn place these ideas within a collective of several theories that together form the complexity theory. This emphasis on contingency further connects our starting point with the book's broader theoretical approach. Different types of path-dependency analysis focus on different types of sequences of events. We subscribe to the notion of reactive sequences, which is a form of analysis especially suited to historical narrative accounts (Mahoney 2000). These reactive sequences are temporally ordered and causally connected and reactive in the sense that events are at least partly reactions to - and thus dependent on - earlier events on which the historical event setting the chain in motion is at least partly contingent (Mahoney 2000; Pierson 2000b). To avoid the problem of infinite regress (i.e., the endless pursuit of contingent events or reasons), conjunctures - intersection points between two or more prior sequences - are often treated as the initial contingent occurrences (Mahoney 2000). Therefore, we concretely set out to uncover the sequence of events which have resulted in the contingent conjuncture that has since led to the three countries' current interest in QAE.

\section{Individual paths towards quality assurance and evaluation}

\section{Brazil: rapid pace towards assessment, slow pace towards quality}

Brazilian education is closely connected with the country's socio-economic and political development. During the centuries of colonisation (1500-1822) and decades of empire (1822-1889), schools were scarce and primary education was a luxury of the elite. The First Republic (1889-1930) introduced a federal 
system and consolidated educational decentralisation. The first Brazilian Constitution (1891) recognised the states as the main providers of basic education and made the federal government responsible for higher education (Romanelli 2007 [1978]).

Historically, federalism became associated with the democratisation and decentralisation of political power (e.g., Souza 2002). Democratisation and decentralisation, in turn, became discursively connected with regionalism. On the one hand, because of Brazil's huge area, "regionalism" describes the socio-cultural and linguistic diversity of its geographical regions. Decentralisation became tied to the regional diversity which shaped Brazilian identity. On the other, "regionalism" refers to regional inequality and disparities in population concentration, resources, and socio-economic and educational development. Decentralisation became tied to federalism, a political system which allows cultural heterogeneity while seeking to counter-balance, or accommodate, socio-economic heterogeneity (Souza 2002). However, by 1891 , federalism was benefiting the autonomy of the states' oligarchies, weakening the federal government, increasing regional disparities, and creating disparate policies (Romanelli 2007 [1978]). The states failed to expand education policies, and gaps in education increased. The 1920 census showed a $72 \%$ illiteracy rate among the population over the age of five (Haddad \& Di Pierro 2000).

A growing urban middle class and an engaged intellectual community, with social discontent and the decline of the oligarchies, paved the way for the 1930 revolution, when there was a civil-political restoration (1930-1937). A synergy between educationalists' vigorous demands and democratic efforts led to a political commitment to education planning. The 1932 reform modernised secondary education (Dallabrida 2009). The 1934 constitution designated national education as the responsibility of the federal government, and the Ministry for Education and Health was created. Two key institutes were established: in 1934, the Brazilian Institute of Geography and Statistics (the IBGE, until 1937 the INE), and in 1937, the National Institute for Educational Studies and Research (the INEP, previously the INP). The IBGE provides Brazilian socio-economic indicators, census, and other statistics analysis; the INEP is responsible for all large-scale assessments and other education studies and data.

This intellectual and socio-political unity rapidly broke down, and both the education and political fields were fragmented in conflicting positions. In 1937, President Vargas installed a dictatorship (1937-1945), and the 1937 constitution reduced the government's responsibility for education. However, Vargas continued to see education as an instrument for the construction of the nation (Peixoto 1995), and the corporatist regime maintained ties with certain educationalists (Centeno 2010). The 1942 reform sought to respond to rising social demands for post-primary education and the requirements of industrialisation. The country still struggled with the provision of universal access to primary education. Despite growing enrolment rates, educational provision fell far short of meeting social demands (Oliveira \& de Araújo 2005). 
The Second Brazilian Republic (1946-1964) re-established civil rights. The 1946 constitution reaffirmed the government's responsibility for national education and legislated for compulsory free primary education. Populist governments emphasised a developmentalist industrialisation project, and education efforts concentrated on technical training at the expense of primary education (Centeno 2010). The states expanded their education systems; appropriate pedagogical-administrative planning was, however, absent (Nardi, Schneider, \& Rios 2014).

At the end of the 1950s, educationalists identified major education problems, some of which are still present: insufficient school expansion; lack of equal opportunities; high dropout and retention rates; inadequate infrastructure, materials, and curricula; and a largely untrained teaching body (Moreira 1956). In 1961, after thirteen years of lively debate, the first Education Law established common national guidelines. The main education indicators were the national census and statistics concerning school enrolment, dropouts, and retentions. QAE practices and policies were neither problematised nor envisaged until the 1970s, as elaborated elsewhere (Kauko et al. 2016).

Populist governments tried to accommodate social demands and allowed a vibrant education community but faced strong political and socio-economic instability. A society fragmented into sectors with divergent interests (Ianni 1975) was the backdrop for a military coup and dictatorship (1964-1985). The military governments restricted civil and political rights. Education initiatives were tailored to meet the government's ideological purposes and economic requirements. The government's alphabetisation programmes (MOBRAL) were particularly well-received by international organisations like the United Nations Educational, Scientific and Cultural Organisation (UNESCO).

Nevertheless, the lack of or insufficient planning for mass education raised serious issues at the state level. In the 1970s and 1980s, the states started to develop performance assessments to collect information about issues as diverse as teacher training, curricula, school materials, and students' progress (Gatti 1987). The World Bank collaborated with many of these state programmes (Gatti, Vianna, \& Davis 1991).

The Ministry of Education also supported programmes which improved school access and pupils' performance in the country's poorest regions (Horta Neto 2007). The most famous was the Northeast Basic Education Project (EDURURAL), which the Ministry of Education had planned in 1977 (Horta Neto 2007) but which was only implemented in 1980 with a loan from the World Bank. The first large-scale assessment involving more than one state was developed within this project in response to a request from the World Bank's project evaluation (Gatti, Vianna \& Davis 1991). In 1984, the Ministry of Education and the World Bank began conceiving the Second Northeast Basic Education Project, but the agreement was only signed after ten years of negotiations (Horta Neto 2007). Until the mid-1980s experiments with learning assessments in Brazil were discursively and pragmatically inconsequential and were still neither framed nor understood as QAE practices and policies. Indeed, 
the notion of quality was rather contested in the educational field because of its historical association with elitist education and political conservatism (Centeno, Kauko, \& Candido 2017).

With the end of the military dictatorship in 1985, socio-political movements and education debates returned (see Chapter 4). Brazil faced economic adjustments (Wirth 1997) and pressure from the international system, including the World Bank and the International Monetary Fund, to structurally reform. The transitional government began a managerial reform of public administration. Total quality management emerged as a particularly good solution for the country's managerial problems (Longo 1996). Although such programmatic incursion into education had little practical impact, it triggered an important public debate. While the education community strongly contested its application to education, policymakers, economists, and sociologists embraced the educational "total quality" perspective (Centeno, Kauko, \& Candido 2017). This discussion brought the notion of education quality to the fore. A new political discourse, in which quality in education was associated with assessment, emerged.

In the 1980s, instead of substantial reforms, the states attempted to regularise school progression (in other words, without retention) through measures such as automatic grade progression, the provision of acceleration classes, and the reorganisation of studies into cycles (Franco et al. 2007). These ad hoc and palliative policies compromised traditional statistical indicators and weakened trust in official statistics (Oliveira \& Araújo 2005). From the late 1980s, the United Nations Development Plan (UNDP) promoted the improvement of education information systems at both state and national levels. Projects in 1986 focused on managerial training for basic education, support for methodological development, and the provision of the State Secretariat of Education with the necessary equipment for data collection and analysis, besides staff training (Coelho 2008). The UNDP has been playing an important role in collecting, organising, and disseminating data, including education data (this culminated in "The Human Development Atlas in Brazil": see www.atlasbrasil.org.br/2013/ en/home/).

In 1987, the INEP designed a programme of external assessment to evaluate pupils in public schools (Vianna 1990) and provide information to the states about learning problems. The Ministry of Education and some states committed to this programme (Horta Neto 2007), but the project did not affect public policies as expected because of constant personnel changes in the Ministry of Education (Gatti, Vianna \& Davis 1991).

Nevertheless, this allowed the INEP to build its own expertise (see Chapter 5). This experience, together with the knowledge developed by the Ministry of Education in EDURURAL, facilitated the creation of the first nationwide large-scale assessment in 1988 (Horta Neto 2007): the Evaluation System of Public Primary and Lower Secondary Schools (SAEP). Resources for its planning and implementation were still sourced from a loan agreement with the World Bank (Coelho 2008), but the federal government postponed its launch 
for financial reasons (Gatti, Vianna \& Davis 1991; Horta Neto 2007). The SAEP provided the technical grounds for the assessment of basic education (Bonamino \& Sousa 2012). It was the first in an avalanche of national and international assessments which progressively covered the whole education system (see Kauko et al. 2016).

A strong democratic movement progressively and irreversibly took hold in the 1980s, leading to the 1988 constitution and the first direct presidential elections in 1989. Federalism, decentralisation, and democracy were again entangled in constitutional debate. The 1988 constitution reinforced federalism by empowering municipalities with responsibility for education, but it ignored its financial and political impact and fuelled federal conflict (Araújo 2010). Decentralisation resumed and strengthened. Where decentralisation to sub-national governments is concerned, Brazil is considered the most decentralised higherincome country (Souza 2002). The national education scheme was reorganised according to the government level, and school autonomy was progressively enforced (Meade \& Gershberg 2008).

An ambiguity concerning decentralisation is reflected in the proliferation of attitudes which see it as an obstacle or even as a factor in Brazilian education disparities (see Romanelli 2007 [1978]; Alves 2007; Dourado 2007; Franco et al. 2007; Goncalves \& Franca 2008; Sobreira \& Campos 2008; Souza \& Costa 2009; Durham 2010). However, for many who support national standard measures such as a core curriculum, decentralisation is still strongly tied to diversity, and references to a unified or centralised education system are therefore not only mistaken but also carry negative political connotations, which all actors, regardless of their position in the education arena, seem keen to avoid (as our interviewees vividly confirmed).

The text of the 1988 constitution also contributed to the understanding of education as an individual and social right. It guaranteed the universalisation of access to free compulsory basic education, equality of educational opportunities, and non-discrimination. However, it associated education quality with education assessment (Freitas 2004; Coelho 2008; Gusmão 2010). The assurance of quality became a central aim of education policy. Some held that the assessment of education quality by the government was a means of allowing private education to continue, while attempting to control it (Coelho 2008). The assessment of private schools logically implied the assessment of public schools (Freitas 2004). The SAEP was transformed into the SAEB (Evaluation System of Basic Education, see Chapter 7), "basic" replacing "public" to include assessment of private schools (Horta Neto 2007). The implementation of the SAEB in 1990 was assisted by the UNDP and funding from the World Bank (Coelho 2008).

In 1996, the National Education and Framework Law (LDB) entrenched the decentralisation of education, which was successively redefined by further amendments (see Law 9.394). Currently, municipal systems are broadly expected to provide pre-school and elementary education (for 1- to 14-yearolds), while the state systems are expected to cover the remaining compulsory education (for 15- to 17-year-olds). The federal government is responsible 
for providing the necessary technical and financial backing to federal units. However, municipal and state systems frequently overlap, and this (dis)articulation between the three levels still presents many problems (Candido, Kauko, \& Centeno submitted). Educational decentralisation has neither simplified education planning and political-fiscal mechanisms nor reduced inequalities between federal units, among the population, or even among schools (see Oliveira \& Santana 2010).

UNESCO and other international organisations supported the Brazilian educational reforms of the 1990s. The 1990s World Declaration on Education for All (EFA) and UNESCO's education quality agenda greatly influenced the education debate and the implementation of QAE mechanisms. The UNESCO Regional Bureau for Education in Latin America and the Caribbean (OREALC) hosted the Latin American Laboratory for the Assessment of the Quality of Education (LLECE), which began to conduct regional large-scale assessments in 1997.

The SAEB went through several technical changes. It was reformed (1995), consolidated (2005), and enlarged (2013). The UNDP continued to enable these methodological developments and the acquisition of expertise by financing INEP staff training (in Brazil and abroad) and facilitating international technical cooperation (see Coelho 2008). The UNDP employed - and still employs - Brazilian technicians and officials working in the INEP, for example (interview data). Despite the critiques of data production by the national government (see Chapters 5 and 7), assessments are frequently justified in the education arena as a counterpoint to the complex decentralised Brazilian system. Our interview material suggests that inequalities and disparities, with a lack of information and central control resulting from strong decentralisation, were the basis for the restructuring and expansion of QAE education policy between 2005 and 2009 (see Kauko et al. 2016).

Another fundamental development in QAE was the creation of a major index from the school census (statistical data) and SAEB data (students' achievements), the Development Index of Basic Education (IDEB), which is regarded as the main indicator of Brazilian education quality. The IDEB was developed alongside the 2007 Education Development Plan, which set the goal of achieving the OECD's Programme for International Student Assessment (PISA) mean score by 2021. The recent National Education Plan (PNE 2014-2024) reiterated this goal. The OECD and ETS (the Educational Testing Service leading the PISA consortium) trained Brazilian technicians in the early 2000s (interview data). Brazil has been vice-chair of the PISA Governing Board since 2013.

In the broader political and socio-economic context, Brazil entered the twenty-first century with a promising framework. For the first time since the end of dictatorship, Cardoso's stable democratic government (1995-2002) was in power. Cardoso tackled economic restructuring, implementing managerial and efficiency reforms in all sectors of public administration (Derqui 2001). Lula da Silva's Workers' Party government, which succeeded Cardoso, governed in a context of progressive socio-political growth (2003-2010). The Lula 
government ensured an unprecedented political continuity in Brazil. However, the socio-economic and political situation deteriorated rapidly during the next Workers' Party government of Dilma Roussef (2011-2016), which culminated in impeachment. Socio-political contestation and economic recession have continued under the Temer provisional government (2016 to present). Labour and social security reforms are internally highly controversial, although they are praised by international economic agencies and financial markets. The reform of secondary education provokes diverging opinions. Currently, the minimum wage is US $\$ 297$ and the unemployment rate continues to grow (hitting $13.7 \%$ in March 2017, IBGE). The media has described people's growing difficulties (e.g., Phillips 2017).

The Brazilian socio-political pendulum swung dramatically between democratic and authoritarian governments until the mid-1980s, but despite this socio-political turbulence, there was an expansion of education opportunities (e.g., Oliveira \& Araujo 2005, Klein 2006, Oliveira 2007, Gouveia \& Souza 2013). Since the 1990s, Brazilian education has been subject to relentless QAE policies. Although many - if not all - the problems experienced between the 1950s and 1980s have persisted, educational progress has occurred. Despite the current turbulence, this is likely to continue. When we were in the field (2015/2016), Brazilian opinions about the future on the national level were hopeful (see Chapter 8), while locally they were very mixed (interview data). Currently, a broader pessimism can be sensed in informal local feedback from interviewees, and it is also noticeable in many media interviews with experts holding contrasting political and educational views (e.g., Daniel Cara, Folha de São Paulo, 10 October 2017; Ricardo Paes de Barros, Istoé Dinheiro, 8 September 2007).

The same education problems persist but with changes in their depth and breadth. As one interviewee concisely stated, improvements occur continuously but at a slow pace and appear to frustrate progress - always taking place but never matching initial expectations.

\section{China: imperial legacies and the needs of the party-state - "QAE with Chinese characteristics"}

The Chinese education system has been strongly influenced and shaped by Chinese cultural and intellectual traditions, especially Confucianism (Lee 2000). During the millennia-long imperial era, the state's direct involvement in education was very limited, and education was for the privileged few, even if formally everyone could achieve social mobility through the open civil service imperial examinations (keju), which also served as a rudimentary assessment system for future government officials (Han \& Yang 2001; Postiglione 2011). To this day, this heavy emphasis on examination performance looms over the education system, complicating many efforts at reform. During the imperial era, there was also a system called the inspection of learning (shixue), under which emperors and local governors acted as education inspectors (Hong 1991). After the 
abolition of the imperial education system in 1905, which was followed by the fall of the last imperial dynasty in 1912, foreign, and especially Western, supervision practices began to be studied and borrowed (Han \& Yang 2001; Lee 2000). Further development, however, was stalled for decades because of internal conflict, war, and social turmoil (Han \& Yang 2001).

It was this context of a decentralised elitist system with a huge illiterate population which allowed the Chinese Communist Party (CCP), established in 1921, to grow in influence (Postiglione 2011). After the rural-poor supported communist victory over the nationalists in the civil war the People's Republic of China (PRC) was established in 1949. The decentralised and largely private education system was nationalized, and the Ministry of Education took over as the highest central authority dealing with education issues (Hong 1991; Meisner 1999). This centralised model of education governance largely followed the Soviet model (Meisner 1999; Postiglione 2011). In the following decades, education policies fluctuated between the moderate and radical, mirroring the general political situation. In the most radical phases, even hinting about learning from Western capitalist countries was an offence approaching treason. To cater for the needs of the rural poor who had helped the Communist Party gain power, in the first decades of communist rule, education served mainly ideological, economic, and political requirements, and egalitarianism was the expected targeted standard (Chen Cravens, Chu \& Zhao 2011; Han \& Yang 2001). Throughout the country, education was uniformly organised and political orthodoxy was prioritised. The centralisation of the education system also covered matters related to supervision. An inspection office (shidaosi) took over the task of assisting education governance through the inspection of schools (Hong 1991). However, despite the communist victory in the civil war and the subsequent nationalisation of education, uncertain times continued. The restored supervision system and the rest of the education system were severely disturbed by the turmoil of the Cultural Revolution - the most radical of the early political campaigns of the People's Republic of China. According to the extreme leftists' view within the Chinese Communist Party, the revolution needed to be continued and deepened, as this task had been neglected after the establishment of the "New China".

It was only after Mao's death in 1976 that Deng Xiaoping, the country's new de facto paramount leader, began to restore the education system after the turmoil of the Cultural Revolution (Hong 1991; Postiglione 2011). Under his reforming leadership, China adopted an economic reform policy known as "Reform and Opening Up" (gaige kaifang). Opening the Chinese economy and society to foreign trade and ideas was essential to this programme so that "socialism with Chinese characteristics" - an economic system combining a traditional socialist politico-economic system with a market economy - could be established (Meisner 1999). In reforming the Chinese economy with the help of foreign expertise - which now included ideas, practices, and products from the West - the revitalisation and reform of the education system played a central part. Education became a strategic priority because of its crucial link 
with the promotion of national development and its furthering of the state's economic aspirations (Chen Cravens, Chu \& Zhao 2011). In a country where, despite the progress made during the Mao era, even basic infrastructure and access to education were severely lacking, efficiency and quality of education were naturally defined in quantitative terms. Later the focal points of this quantitative improvement, with its twin goals of universalising nine-year compulsory education and eradicating illiteracy, became known as the "Two Basics" (liangji) (Postiglione 2011).

To ensure that these quantitative improvements would succeed, the supervision system also had to be re-established. Consequently, in 1983, the Ministry of Education released a formal document calling for the re-establishment of education supervision in all provinces. The legal framework guiding the work of supervision has since been completed (Yang 2001; Dahlman, Zeng, \& Wang 2007). Under this model, the supervision system (dudao) has two basic purposes: administrative (duzheng) and education inspection (duxue). Administrative inspection is tasked with ensuring that local governments fulfil their responsibility to provide the necessary funds, facilities, and resources for the development of education. Education inspection in turn is intended to ensure that schools follow relevant education laws and policies (Huang 2009; Jin 2004; Yang \& Guo 2005). A four-layered supervision network extending from the national to sub-national city and county levels has slowly been implemented (Hong 1991; Lee, Ding, \& Song 2008).

With the help of the re-established supervision system, China was able to achieve most of the goals of the "Two Basics" by the end of the twentieth century - a feat rarely achieved by other developing lower-income countries (Chen Cravens, Chu \& Zhao 2011; Postiglione 2011). Meanwhile, economic reform had succeeded in launching the People's Republic of China on an unprecedented trajectory of double-digit economic growth, which helped pull hundreds of millions of Chinese out of poverty - a remarkable feat by any standard (Meisner 1999). However, exposure to Western ideas and marketoriented reforms also brought new problems. Income inequality, inflation, and corruption increased, and demands for political reform strengthened during the 1980s. The decade's ensuing political unrest culminated in the 1989 crackdown on the Tiananmen Square protest in Beijing. The Chinese Communist Party has been greatly preoccupied with its legitimacy ever since, and consequently, to legitimise itself and stay in power, maintaining economic growth, social stability, and national unity have been the party-state's top priorities (Laliberté \& Lanteigne 2008; Zhu 2011). As Chapter 4 illustrates in more detail, a cautious stance towards foreign influence remains perhaps the most enduring legacy of the unrest of 1989, because it is seen as a major contributor to the unrest.

Although economic growth initially slowed after 1989, education reform to maintain it has only intensified since the 1990s (Postiglione 2011). As the basic quantitative targets had largely been achieved by then, reflecting a larger societal trend whereby all human resource decisions were justified in terms of quality, emphasis in education increasingly shifted from quantitative to qualitative 
improvement (Kipnis 2006; Law 2007; Liu 2008). Following this shift in focus, and largely inspired by academics now familiar with Western ideas and practice, the notion of "quality education" (suzhi jiaoyu) appeared in the education agenda. The notion gained momentum in the 1990s as a guiding principle of education policy, and it soon became a catchphrase for Chinese policymakers, the media, and the general public (Chen Cravens, Chu \& Zhao 2011; Della-Iacovo 2009; Kipnis 2006). Since its first appearance in the mid-1980s, the wording has been used in policy resolutions and reform plans, and in the revised (2006) version of the 1986 Compulsory Education Law, quality education was promoted from a policy to the legal level for the first time (DellaIacovo 2009; Law 2007; Liu 2008). Consequently, new policy orientations place more emphasis on efficiency, practicality, plurality, students' all-round development, and the measurement of student and school outcomes, although the ultimate goal of quality education is still to assist the party-state in its quest for national rejuvenation (Chen Cravens, Chu \& Zhao 2011; Han \& Yang 2001; Della-Iacovo 2009, Xin \& Kang 2012). As Belinda Della-Iacovo (2009: p. 242) explains,

The ultimate goal of suzhi jiaoyu is national strength. The government has identified the skills China's workforce needs to acquire which it sees as critical to sustaining its modernisation drive. Practical skills and innovative ability have been identified by the leadership as areas which need to be improved in order to raise China's global competitiveness.

In addition to this qualitative turn, other notable changes also took place in the Chinese education field around the same time. First, following a broader shift in Chinese society towards market practices, the education system also became increasingly market-driven as a result of a policy known as "entrepreneurialising education" (jiaoyu chanyehua), which emerged in the late-1990s (Ngok 2007; Qi 2011). As Gerard A. Postiglione (2011: p. 85) asserts, "Markets have come to matter more than Marxism in educational provision, especially as more needed to be paid for quality education". Second, by the early 2000s, the idea of a "scientific outlook on development" (kexue fazhan guan) was gaining ground in the political leadership. These ideas consolidated the notion that policymaking in the field of education should also be based on evidence and science (Chen 2010; Zhang 2010; Xu \& Li 2011).

With the change in the definition of quality in education, new measures to ascertain that it is achieved have been required. Consequently, the reform of the testing, evaluation, and assessment system has played a central role in promoting and improving the quality of the education system (Han \& Yang 2001; Liu 2008; Peng, Thomas, Yang \& Li 2006; Xu \& Li 2011). Most notably, this change has manifested itself in the construction of the assessment (jiance) system headed by an institution known as the National Assessment of Education Quality (NAEQ, Jiaoyubu Jichu Jiaoyu Zhiliang Jiance Zhongxin), which was piloted in 2007. This formally independent system managed by the NAEQ 
runs in parallel with the supervision system by operating on the four already mentioned levels. However, its main purpose differs from that of supervision. The jiance system is tasked with gathering data through standardised tests, which are then utilised in policymaking and system development (Chen 2010; Fan \& Liao 2013; Wang \& Zhang 2009; Zhang 2010; Zhou 2012). Rhetorically at least, this assessment plays a central role in contemporary Chinese compulsory education. We examine the system's various aspects, as well as its disparity between rhetoric and practice, in more detail in Chapters 4 and 6. Several other reforms, such as curriculum reform, which touch on QAE have also been initiated.

At the beginning of the twenty-first century, the People's Republic of China is arguably both politically and economically a regional and global powerhouse. China's share of world gross domestic product has risen to double digits, and after four decades of economic reform, the Chinese population has become increasingly rich. Access to all levels of education has grown exponentially, and illiteracy among young people has been virtually abolished. Many problems persist, however. Despite the economic progress of the last forty years, political reform has lagged. No change has been made to the fundamental structure of the political system since the events of 1989, and the ultimate authority to make policy still resides with the Chinese Communist Party. This is also evident in the field of education, where regulations and overall plans are still largely formulated by the Ministry of Education, whereas sub-national authorities are mainly responsible for implementing policies by adapting to local conditions (which sometimes entails risking the circumvention of central policies) (Postiglione 2011; Qi 2011). Although some flexibility and innovativeness are allowed, all local adaptations must be done within the general framework, and it is primarily the workload - not the authority - which has been transferred downwards (Harris, Zhao, \& Caldwell 2009; Ngok 2007; Qi 2011). Tingting Qi (2011: p. 34) has aptly described this phenomenon as "centralised decentralisation". Although the fundamentals of the system remain unchanged, this does not mean everything has remained the same. Jessica C. Teets (2013) has noted that a new model of state-society relationship, which she calls consultative authoritarianism, is emerging in Chinese society at large. She suggests (ibid.: p. 32) this reformed form of governance

merges the regulatory-state idea of a relatively autonomous civil society collaborating with the state to solve social problems with the New Left idea of state guidance of groups to protect society from narrow interest groups and social instability. This model is characterized by two main aspects - a pluralistic society participating in policy formation and implementation, and the use of multiple indirect tools of state control.

As we shall see in Chapter 4, these tendencies have also been evident in the structure of the current QAE system in Chinese compulsory education as new stakeholders in the field have emerged. The continued emphasis on testing and 
examination performance, which dates to imperial times, still largely structures systems (Postiglione 2011). As our interviews also indicated, the influence of these practices is so strong and pervasive that wordings such as promotionoriented education (shengxue jiaoyu) or examination-oriented education (yingshi jiaoyu) are today staple features of the vocabulary of Chinese educational discourse: the perceived negative influences of these continuing practices were frequently mentioned by our interviewees. Resource issues also persist. Many rural schools still lack qualified staff and facilities (Robinson \& Yi 2008). Indeed, the economy's exponential growth has given rise to new types of inequality. There is not only a gap between different areas and provinces today, but the gap between counties and even schools - of which a growing number are now privately run - in the same locality is continually growing (Gustafsson, Shi, \& Sicular 2008; Huo \& Gao 2006).

\section{Russia: quality control reinforcing central regulation ${ }^{1}$}

School education in Russia has been facilitating state development projects since the tsarist era. Two distinct societies and cultures, the elite and the peasantry, co-existed in imperial Russia, and by the beginning of the twentieth century, teachers in peasant schools were expected not only to spread literacy but also to play the role of political mediators, who would assist in the implementation of the state's political and economic strategy for Russia's vast rural community (Seregny 1993: pp. 121-122). In Soviet Russia, education was of major importance to the effort to build a society of egalitarianism and solidarity. Schools were to equip students with everything needed for their effective future contribution to the socialist economy and to the project of building communism. Hence, alongside the development of students' skills and knowledge, schools were involved in ideological indoctrination. The Stalinist school model was developed in the 1930s after a decade of pedagogical experiments, and it reinstated many aspects of pre-revolutionary education, such as the teacher's dominance of the classroom and strict adherence to a centralised curriculum (Byford \& Jones 2006: p. 422). The main characteristics of the Stalinist school were rigid discipline and hierarchy, the enormous quantity of information students were expected to absorb, and an emphasis on collectivism and patriotism. The state assumed full responsibility for guaranteeing free and equal access to education, as well as its quality. At the same time, it was the duty of every (future) citizen to attend school and to study to the best of his or her ability to develop into an efficient member of socialist society (Livschiz 2006: p. 559). Students' commitment to learning was overseen by school workers, student organisations in which every student was enrolled from grade one, and local organs of the Communist Party, which exerted influence over parents at their workplaces.

The main instruments of quality control during the Soviet era were inspections, school reports, and the school census. In 1944, a system of grades and examinations was established. Students' outstanding results were symbolically 
rewarded with gold and silver medals. There was no centralised national examination, and school-leavers' educational achievements were assessed by schools under the supervision of the local education authorities. It was assumed that a centralised curriculum and teacher training, given that schools were provided with sufficient resources, effectively ensured a high standard of education and its relevance to the current needs of the state (West \& Crighton 1999). Until the education reforms of the 2000s, the grades of students and their related indicators, such as the percentage of students successfully transitioning to the next school year or the numbers of graduates awarded medals, served as the main measures of quality (see e.g., Bakker 1999: p. 296). Assessment of schools and teachers on the basis of students' grades was prohibited by the decrees of the 1940s, and competition in socialist education was discouraged (Mayofis 2015: pp. 40-41). Regular school inspections ensured teachers' objectivity in their assigning of grades:

The mark ... should reflect the true knowledge of students. When fighting the poor progress of students, one should not follow the path of lowering the standards, as some teachers tend to do. Only through raising the standards the quality of knowledge can be improved.

(from an article in the Teacher's Newspaper, 1948, quoted in Mayofis 2015: p. 82)

Despite the appearance of state control over every aspect of school life and the constant improvement in quality, Soviet education faced many challenges. The country's vast size, its social and ethnic diversity, and the enormous differences between the Soviet city and countryside contributed to the large variety of implementation methods for centrally designed education policies. In the aftermath of the economic and social devastation of collectivisation and World War II, schools were severely underfunded, and post-war state statistics registered massive dropouts and repeating of study years (Livschiz 2006). Teachers were blamed for this: they were accused of "formalistic" teaching approaches and lacking the necessary pedagogical skills (Mayofis 2015: pp. 61-64). Between 1940 and 1956, schools charged tuition fees for grades 8-10, making education at this and higher levels virtually unaffordable to poorer families, especially in rural areas. Studies of Soviet education consistently point to its persistent inequality (Byford \& Jones 2006).

Ideas about the mission of education in Russia started to change under perestroika in the 1980s. The key idea of perestroika was to reorganise the social and political sphere to allow for more freedom and truth. In education, this was interpreted as a call for more democratic and student-centred schools. A group of educators within the Academy of Pedagogical Sciences, called VNIK "Bazovaia shkola", proposed a critical reform of the Soviet school. They suggested a set of new basic principles: democratisation, humanisation, differentiation, openness, continuity, and a developmental approach to education. They also promoted greater participation by school staff in a wide range of decisions 
concerning schoolwork, claiming that "educational processes should be governed by those who teach" (Long \& Long 1999: p. 88). School administration was envisioned as a communal enterprise which should involve students and parents, as well as teachers and civil society representatives, to better serve local needs. Another phenomenon of the 1980s which facilitated education reform was the movement of "innovative teachers" (pedagogi-novatory). These teachers offered creative teaching methodologies with a focus on students' individual abilities and interests, demonstrating that this greatly increased students' learning. In 1986, they formulated the proclamation of "Cooperative Pedagogy", based on partnership between teacher and student. The concepts and methodologies of innovative teachers were disseminated in courses, seminars, and media sources.

The ideas advocated by VNIK and innovative teachers became the basis of the new Law on Education in 1992, following the dissolution of the Soviet Union. The leader of VNIK, Eduard Dneprov, became the first minister of education in post-Soviet Russia. The new law also enabled the decentralisation of education to support school-level management, allow schools to tailor the curriculum to local needs, and facilitate school choice for families. The government's administrative and fiscal responsibilities were shifted to regional and local education authorities. However, the call for democratisation, humanisation, and differentiation was not the only factor in the dramatic changes in Russian education. The economic crisis of the early 1990s caused severe underfunding. The abrupt transition to a market economy led to the reinterpretation of education as a service and the partial privatisation and commercialisation of the school sector. Alongside the legislation for decentralisation, inequality in education sharply increased (Polyzoi \& Dneprov 2011).

While the central authorities lacked financial resources, new education initiatives were financially supported by international philanthropic foundations, especially the Soros Foundation (Startsev 2012). Other international organisations, including the World Bank and the OECD, started working in Russia in the 1990s. They encouraged efforts to democratise and differentiate education and suggested the implementation of a more thorough and modern system of quality assurance, which would include nationwide quality standards and external quality evaluation mechanisms and involve diverse stakeholders in the QAE process (OECD 1998; World Bank 1999). World Bank experts regarded the lack of standardised achievement testing providing commensurable national statistics as an absence of QAE policy (World Bank 1995). Both the World Bank and the OECD recommended standardised testing as a key quality evaluation mechanism. At the same time Russia started participating in international large-scale assessments, TIMSS (Trends in International Mathematics and Science Study) was undertaken in 1995 and 1999, and Progress in International Reading Literacy Study (PIRLS) and PISA were added in the 2000s. The methodology of these tests and their sociological perspective served as a source of inspiration for Russian scholars, who conducted meta-analyses of test results and designed similar national instruments (Piattoeva \& Gurova 2018). 
Ideas about education quality and its evaluation changed in line with the developments of the 1990s. Quality came to be understood as intrinsically diverse, based on "customer" needs and context-bound. Assessments were addressed primarily as a tool for school and classroom internal diagnostics with the overarching aims of the effective management of schools and meeting the needs of students and parents. At the same time, the literature on school management published in this period promoted an evidence-based and goaloriented approach and insisted that education outcomes, although specific to each school, should be measurably defined and accompanied by a set of indicators (e.g., Tret'iakov 1997). The development of measurements in education was also powered by an increasing interest in ability testing, which had been banned during the Soviet era, and the rise of information technologies, which opened new possibilities of collecting and processing large quantities of data. While these new ideas were not reflected in the education legislation of the 1990s, they arguably prepared the ground for the changes of the following decade.

At the beginning of the 2000s, with the recovery and growth of the Russian economy and change in political leadership, new education reforms were launched. The Ministry of Education issued several key documents: the National Doctrine for Education (2000), the Concept of Modernization of Russian Education (2001), and the Federal Strategic Program for the Development of Education (2005). These documents defined the mission of education primarily in economic terms: education should contribute to socio-economic growth, serve the needs of the labour market, promote innovation, and ensure the global competitiveness of the Russian economy. They supported the further introduction of market mechanisms to the education sector and called for efficiency, accountability, and transparency in education. These ideas accorded with the recommendations of international organisations and were in line with general performance management reforms in Russia (Gounko \& Smale 2007; Gusarova \& Ovchinnikova 2014). In 2001, the World Bank started its Education Reform Project in Russia, aiming to "improve quality and standards; promote the efficient and equitable use of scarce public resources for education; modernize the education system". The project was launched at the federal level and piloted in three Russian regions. Its intention was to introduce quality monitoring and statistics, based on a new system of assessing student outcomes in the governance of general education (World Bank 2001).

Several major instruments of quality assurance and evaluation were introduced in the educational reforms of the 2000s. The Ministry of Education outlined "state standards", to which school curricula were obliged to conform. New procedures for the licensing, attestation, and accreditation of educational institutions were developed, ensuring schools and universities complied with central regulations and produced satisfactory results. In 2001, the national school-leaving examination (the Unified State Exam, USE, or GIA-11) was piloted in several regions, and in 2009, it became compulsory for all schoolleavers. The examination combined the functions of the school graduation test, the national university entrance test, and the source of national statistics 
on educational achievement (see Chapter 8 for more details on the USE). The Unified State Exam was claimed to facilitate fairer access to universities by assessing school-leavers objectively and impartially and to improve the quality of education across the country, fostering compliance with the official curricula. Thus, the USE was designed to contribute to greater equality for school-leavers and address the negative effects of the radical decentralisation of the 1990s. It also served as an important source of objective information for evidence-based policymaking, which was perceived as indispensable for modern regulatory methods. The national academic discussion between 2000 and 2010 also shifted its focus from school-based, customised evaluation of a largely qualitative nature to depersonalised, often numerical data on educational achievement generated by national and international assessments.

The latest State Program for Education Development (for the years 2013 to 2020) includes a programme for "the development of the system of quality evaluation of education and transparency of the education system" as one of its main elements. The national QAE system outlined in this document comprises action for the state regulation of education, assessment of educational achievement (the national examinations (GIA) after grades 9 and 11), procedures for independent quality evaluation, and the participation of Russia in international studies (Government of Russia 2012: p. 218). Quality of education is defined primarily as compliance with state standards and high performance in international tests. Scores in national examinations serve as the main indicators of education quality at all governance levels, although the examinations' contents, procedures, and administrative uses continue to be discussed and altered. During the last decade all-Russia measurements of educational achievement have been added to the QAE system to complement national examinations and international studies.

The introduction of QAE instruments facilitated the restoration of centralisation in Russian education. Evaluation procedures and associated performancebased incentives were added to the traditional instruments of quality control, instead of replacing them. Despite appearing to be piloted, national examinations were implemented consecutively in all regions of the country in an authoritarian manner. The state defines quality criteria and controls as both inputs (through institutional accreditation and audit) and outputs (through measurable outcomes) of general education. Researchers argue that Russian education reforms can be characterised as "authoritarian modernisation" and that a neoconservative turn is taking place, legitimised by a neoliberal, apparently Western, rhetoric (Minina 2016). At the same time, the current school system shows significantly more diversity and inequality than in the Soviet era, while national regulations still allow for considerable local variation in implementation. Contemporary education governance in Russia, including QAE instruments, evinces a mixture of Soviet-era legacies, developments from the democratisation and diversification period of the 1990s, and neoliberal influences. 


\section{Identifying commonalities and differences in paths to QAE}

As our work indicates, Brazil, China, and Russia have followed - and to a large degree continue to follow - very different developmental paths in their sociopolitical contexts and in the place of education within the larger contexts of politics and governance. However, towards the end of the twentieth century, the countries' paths intersected as they were shaped by a shared interest in QAE. In each country, a contingent conjuncture can be identified in which different developments converged to shape this interest.

In Brazil, this conjuncture dates to the late 1980s. QAE practices emerged at the same time as massive school expansion, deepening federalism and decentralisation, increased democratisation, public managerial reforms, and cooperation with international organisations. Unplanned development of school access and significant dropouts and retention rates presented a problem, while the democratisation of the country and the consequent political acknowledgement of education as a social right provided a legitimate political framework. The ongoing managerial reforms and experiments with assessments funded by the World Bank and supported by the UNDP offered a solution. The intersection of these contingent developments formed the breaking point which set in motion the implementation of the Brazilian QAE system, which was largely composed of large-scale assessments and quantitative indicators. QAE is viewed ambivalently in the education arena because, although it is criticised by many, it is also recognised as an instrument which can tackle the disparities and inequalities which, despite much progress in education, are still deeply rooted in Brazilian society.

In China, the conjuncture can be traced roughly to the period between the mid-1990s and the early 2000s. First, with the help of established institutions like examinations and the re-established supervision system, the quantitative targets of the "Two Basics" had been largely achieved by then. Second, maintaining economic growth had begun to play an increasingly important role in the party-state's drive to enhance its legitimacy after 1989, while the reform of the education system was crucial to the creation of economic growth. Third, the opening of Chinese society to the world brought new ideas. On the one hand, a growing number of Chinese had become familiar with Western education practice and, as Chapter 4 elaborates, international organisations were also increasingly active in the education field. The notion of quality education suzhi jiaoyu - rose to the national agenda. On the other, ideas about the marketisation of education and the idea of evidence-based policy were also gaining ground. These new ideas changed how quality in education was defined, which in turn directly contributed to the reforms of the QAE system - most notably, the establishment of the jiance system - as new mechanisms to ensure quality were required. However, these processes are by no means complete. Chinese society and education face new and continuing problems. 
In Russia, the conjuncture occurred at the end of the 1990s, when national movements for greater diversity and student-centred education, political concerns of increasing inequality and decentralisation, and international examples of and recommendations for large-scale assessments of student achievement converged. Humanisation and democratisation, as part of the de-Sovietisation of schools, led to a focus on student learning, a diversification of curricula and teaching methods, and the accountability of the school to a wide range of stakeholders. Education inequality increased dramatically because of severe underfunding, the marketisation of education, and a widening of social and economic gaps between families. By the end of the 1990s, the introduction of regional autonomy and transfer of administrative and fiscal responsibilities to local authorities had resulted in widely varying conditions and education practices in different regions. These factors contributed to what the public perceived as an education crisis, and justified the re-instatement of central control over education quality and the quality assurance of education opportunities, both of which had been long-standing prerogatives and social obligations of central government. Participation in international student achievement assessments also contributed to the development of national measurement instruments, and advice from the World Bank and OECD promoted modern regulatory instruments, especially standardised testing, as a source of evidence for policymaking. These developments in the early 2000s resulted in the establishment of a new QAE system based on state standards and national school-leaving examinations. The education system was recentralised through new regulation and under the motto "equal access to quality education".

From increased democratisation in Brazil to concern about regime legitimacy in China and de-Sovietisation in Russia, to name only a few examples, these developmental paths clearly reflected the unique cultures and political systems of the countries. QAE arose as a response to markedly different problems. However, these paths share some distinctive similarities, some of which are evident in all cases. First, in all cases, increased international influence and cooperation played a striking role in the introduction of QAE. Second, in all cases, the marketisation of education and public managerial reforms were an important constitutive factor. Some similarities were either identifiable or more evident in two cases. Although not a factor contributing to interest in QAE per $s e$, it is noteworthy, first, that this interest in QAE did not emerge entirely simultaneously: in Brazil, changes were already evident in the late 1980s, whereas they followed in China and Russia a decade later. Second, China and Russia also resembled each other in the sense that the change at this time towards more student-centred education thinking played a pivotal role in both. Third, the massive education expansion of the previous decades was especially important in Brazil and China. Finally, and most obviously in Brazil and Russia, anxiety about the decentralisation of the education system was also an important factor in growing interest in QAE.

Paths converged only temporarily, as this and the following chapters show. Not only had shared interest in QAE arisen in response to markedly different 
challenges and problems, but also, once operationalised, QAE reforms reflected the obstacles and limitations set by the very different cultural and political settings of the respective countries. Consequently, as the following chapters elucidate, since they were operationalised, QAE reforms in Brazil, China, and Russia have again diverged.

\section{From norm takers to norm makers in the global environment?}

While all this was happening within the countries, they had also begun to engage increasingly with the international community. Brazil had been engaging with international organisations since World War II, and by the 1990s, China and Russia were also involved (see Chapter 4). By 2017, all were members of the most prominent and influential global governance institutions, for example, the International Monetary Fund (IMF), the United Nations, the World Trade Organisation, and the World Bank. To borrow the words of Pu (2012), the countries had gradually become socialised within the international order as responsible norm takers. Since the turn of the millennium, however, there have been signs that Brazil, China, and Russia are no longer content simply to engage with the international community and follow its rules. There are signs that socialisation has become a two-way process, as emerging countries aspire to become norm makers in the international order ( $\mathrm{Pu} 2012$ ). Part of this drive has been the construction of a network of global governance institutions which in part complement and in part compete with the current US and Western-dominated system. With three former Soviet Republics, China and Russia founded the Shanghai Cooperation Organisation in 2001 to further their political, economic, and military cooperation. In 2016, the Asian Infrastructure Investment Bank was launched as a Chinese-sponsored alternative to the World Bank, and in South America, Brazil played a central role in the establishment of the Union of South American Nations. These initiatives belong to the larger global context of increasingly numerous and influential emerging power alliances, which are not limited to the activities of Brazil, China, and Russia (Bava 2011).

Within this wider context, perhaps most notably and interestingly because of their shared membership, the countries are also cooperating under the BRICS framework. In 2001, the acronym BRIC was used for the first time to group Brazil, Russia, India, and China, and five years later, a political dialogue between the countries began. The acronym BRICS was coined in 2010 with the inclusion of South Africa (Keukeleire \& Hooijmaaijers 2014; Pant 2013). Initially, as Luckhurst (2013: p. 252) states, the countries were lumped together because of "the dramatic economic growth predictions for the original four BRICs; the likely importance of their future governance role in the world economy; and the nature or quality of the development of these countries". Since the genie escaped the bottle, justifications for grouping these countries together have been numerous, ranging from their developmental requirements to their 
military stances. From the outset, however, academics, journalists, and politicians have been divided on the grouping's nature, justification, and prospects (Brütsch \& Papa 2013).

It is obvious, however, that the countries themselves have exploited perceptions of imminent commonality. The global financial crisis which began in 2007-2008 provided them with the ideal opportunity to develop common positions highlighting the contrast between a prospering periphery and a struggling core. The historic IMF quota reforms and the threat of a joint walkout from the 2009 United Nations Climate Change Conference if their common minimum position was not accepted served as ideal opportunities to symbolically highlight the "rise of the rest" narrative (Liu 2016; Pu 2012; Stuenkel 2014; Ünay 2013).

The BRICS remain a somewhat informal cooperation platform. However, China and Russia seem especially eager to push their cooperation in a more formal direction (Liu 2016). The establishment of the New Development Bank in the summer of 2014 as an alternative to the World Bank and the IMF and the launch of the "eThekwini Action Plan" to address issues related to foreign policy cooperation mark the first steps on this road (Keukeleire \& Hooijmaaijers 2014; Liu 2016; Stuenkel 2014). Those who question the validity of grouping the countries based on their similarities are for the same reason also sceptical, however, of the prospects for their effort to strengthen cooperation and further institutionalise the BRICS (see, for example, Liu 2016).

Although the BRICS grouping has largely been seen (and has portrayed itself) as politico-economic, there are signs that the countries have begun to cooperate in other areas under the BRICS umbrella - including education. Russia and China, for example, have initiated a platform for higher education cooperation which has been described as aiming "to become a platform for academic and expert cooperation, comparative research, and international educational projects" (Higher School of Economics 2013). Most important, perhaps, the BRICS countries' ministers of education meet regularly to promote education cooperation. At their autumn 2016 meeting, the New Delhi Declaration on Education was unveiled to promote cooperation in education. The declaration included - at least rhetorically - areas of cooperation such as "quality education" and "quality assurance" (The Indian Express, 30 September 2016; Xinhua, 30 September 2016).

Research focusing explicitly on the link between education and the BRICS countries has been scarce, however, and has so far been concerned exclusively with higher education (see, for example, Altbach \& Bassett 2014; Carnoy et al. 2013; Schwartzman, Pinheiro, \& Pillay 2015). Although we do not explore this further ourselves, we hope our contribution paves the way to such new research ventures.

\section{Note}

1 This section draws on earlier research articles, namely Gurova (2017) and Gurova, Piattoeva, and Takala (2015). 


\section{Bibliography}

Altbach, P. G., \& Bassett, R. M. (2014). Nix the BRICs - at least for higher education scholarship. Change: The Magazine of Higher Learning, 46(5), 30-33.

Alves, F. (2007). Qualidade da educação fundamental: integrando desempenho e fluxo escolar [Quality of elementary education: Integrating performance and school flow]. Ensaio: Avaliação e Políticas Públicas em Educação, 15(57): 525-542.

Araujo, G. C. (2010). A relação entre federalismo e municipalização: desafios para a construção do sistema nacional e articulado de educação no Brasil [The relationship between federalism and municipalization: Challenges for the construction of a national and articulated education system in Brazil]. Educação e Pesquisa, 36, 389-402.

Bakker, S. A. (1999). Educational assessment in the Russian federation. Assessment in Education: Principles, Policy \& Practice, 6(2), 291-303.

Baumgartner, F. R., \& Jones, B. D. (2009). Agendas and Instability in American Politics (2nd ed.). Chicago, IL: Chicago University Press.

Bava, U. S. (2011). Emerging power alliances in perspective: IBSA, BRIC, BASIC. In F. Kornegay \& L. Masters (Eds.), From BRIC to BRICS (pp. 55-61). Pretoria: Institute for Global Dialogue.

Bonamino, A., \& Sousa, S. Z. (2012). Three generations of assessments of basic education in Brazil: Interfaces with the curriculum in/of the school. Educação e Pesquisa, 38(2), 373-388.

Brütsch, C., \& Papa, M. (2013). Deconstructing the BRICS: Bargaining coalition, imagined community, or geopolitical fad? The Chinese Journal of International Politics, 6, 299-327.

Byford, A., \& Jones, P. (2006). Policies and practices of transition in Soviet education from the revolution to the end of Stalinism. History of Education, 35(4-5), 419-426.

Candido, H. H. D., Kauko, J., \& Centeno, V. G. (submitted). How has quality in education been problematised in Brazil? Resubmitted after revisions.

Capano, G. (2009). Understanding policy change as an epistemological and theoretical problem. Journal of Comparative Policy Analysis: Research and Practice, 11(1), 7-31.

Carnoy, M., Loyalka, P., Dobryakova, M., Dossani, R., Froumin, I., Kuhns, K., \& Wang, R. (2013). University Expansion in a Changing Global Economy: Triumph of the BRICs? Stanford: Stanford University Press.

Centeno, V. G. (2010). Agency in establishing a transnational space: Brazilian interest in USAmerican educational assistance programs (1956-1974). In U. Engel \& M. Middell (Eds.), World Orders Revisited (pp. 155-176). Leipzig: Leipziger Universitätsverlag.

Centeno, V. G., Kauko, J., \& Candido, H. H. D. (2017). Quality assurance and evaluation through Brazilian lenses: An exploration into the validity of umbrella concepts. Comparative Education, e-publication ahead of print. Retrieved from http://dx.doi.org/10.1080/ 03050068.2017.1348084

Chayes, A., \& Chayes, A. H. (1995). The New Sovereignty: Compliance With International Regulatory Agreements. Cambridge: Harvard University Press.

Chen, X. (2010). 中国的实践:基础教育监测的新尝试 [The Chinese practice: A new attempt at basic education monitoring]. 教育研究, 4, 3-4.

Chen Cravens, X., Chu, H., \& Zhao, Q. (2011). Defining school effectiveness in the reform for quality-oriented education. International Perspectives on Education and Society, 15, 153-185.

Cheng, K., Jin, X., \& Gu, X. (1999). From training to education: Lifelong learning in China. Comparative Education, 35(2), 119-129.

Coelho, M. I. M. (2008). Vinte anos de avaliação da educação básica no Brasil: aprendizagens e desafios [Twenty years of the evaluation of basic education in Brazil: Lessons and challenges]. Ensaio: Avaliação e Políticas Públicas em Educação, 16(59), 229-258. 
Cummings, W. (2003). The Institutions of Education: A Comparative Study of Educational Development in the Six Core Nations. Oxford: Symposium Books.

Dahlman, C., Zeng, D. Z., \& Wang, S. (2007). Enhancing China's Competitiveness Through Lifelong Learning. Washington, DC: World Bank.

Dallabrida, N. (2009). A reforma Francisco Campos e a modernização nacionalizada do ensino secundário [Francisco Campos' reform and the national modernization of the secondary school]. Educação, 32(2), 185-191.

Della-Iacovo, B. (2009). Curriculum reform and "Quality Education" in China: An overview. International Journal of Educational Development, 29(3), 241-269.

Derqui, J. M. G. (2001). Educational decentralization policies in Argentina and Brazil: Exploring the new trends. Journal of Education Policy, 16(6), 561-583.

Dourado, L. F. (2007). Políticas e gestão da educação básica no Brasil: limites e perspectivas [Policies for and management of basic education in Brazil: Limits and perspectives]. Educação \& Sociedade, 28(100), 921-946.

Durham, E. R. (2010). A política educacional do governo Fernando Henrique Cardoso: uma visão comparada [The educational policy of the Fernando Henrique Cardoso government: A comparative view]. Novos Estudos - CEBRAP, 153-179.

Fan, Y., \& Liao, Q. (2013). 基础教育质量监测: 国际经验与本土路向 [Basic education quality monitoring: International experiences and the local path]. 教育导刊, 4, 37-40.

Franco, C., Ortigão, I., Albernaz, Â., Bonamino, A., Aguiar, G., Alves, F., \& Sátyro, N. (2007). Qualidade e eqüidade em educação: reconsiderando o significado de "fatores intraescolares" [Quality and equality in education: Reconsidering the meaning of "withinschool factors"]. Ensaio: Avaliação e Políticas Públicas em Educação, 15(55), 277-298.

Freitas, D. N. T. de (2004). Avaliação da educação básica e ação normativa federal [Basic education evaluation and federal regulatory actions]. Cadernos de Pesquisa, 34(123), 663-689.

Gatti, B. A. (1987). Testes e avaliações do ensino no Brasil [Tests and school evaluations in Brazil]. Educação e Seleção, 16, 33-41.

Gatti, B. A., Vianna, H. M., \& Davis, C. (1991). Problemas e impasses da avaliação de projetos e sistemas educacionais: dois casos brasileiros [Problems and bottlenecks of project evaluation and educational systems: Two Brazilian cases]. Estudos em Avaliação Educacional, 4, 7-27.

Glosny, M. A. (2010). China and the BRICs: A real (but limited) partnership in a unipolar world. Polity, 42(1), 100-129.

Gonçalves, F. O., \& França, M. T. A. (2008). Transmissão intergeracional de desigualdade e qualidade educacional: avaliando o sistema educacional brasileiro a partir do SAEB 2003 [Intergenerational transmission of inequalities and education quality: Evaluating the Brazilian education system from the perspective of SAEB 2013]. Ensaio: Avaliação e Políticas Públicas em Educação, 16(61), 639-662.

Gounko, T., \& Smale, W. (2007). Modernization of Russian higher education: Exploring paths of influence. Compare: A Journal of Comparative and International Education, 37(4), $533-548$.

Gouveia, A. B., \& de Souza, Â. R. (2013). Efetividade da política para o ensino fundamental em municípios Brasileiros [Political effectiveness for elementary education in Brazilian municipalities]. Cadernos Pesquisa, 43(150), 836-855.

Government of Russia. (2012). Gosudarstvennaia programma Rossiiskoi Federatsii "Razvitie obrazovaniia" na 2013-2020 gody [State programme of the Russian Federation "Development of Education" for 2013-2020]. Retrieved from http://минобрнауки.рф/документы/3409/ файл/2228/13.05.15Госпрограмма-РазВитие_образоВания_2013-2020.pdf

Gurova, G. (2017). Soviet, post-Soviet and neoliberal: Governing Russian schools through quality assurance and evaluation. Policy Futures in Education. Retrieved from https://doi. org/10.1177/1478210317743648 
Gurova, G., Piattoeva, N., \& Takala, T. (2015). Quality of education and its evaluation: An analysis of the Russian academic discussion. European Education, 47(4), 346-364.

Gusarova, M., \& Ovchinnikova, M. (2014). Introducing performance management in the system of public administration in Russia: Approaches and lessons learnt from the last decade of implementation. Public Administration Issues, 1, 98-126.

Gusmão, J. B. de (2013). A construção da noção de qualidade da educação [Construction of the concept of quality of education]. Ensaio: Avaliação de Políticas Públicas Educacionais, 94(236), 299-322.

Gusmão,J. B. de (2010). Qualidade da educação no Brasil: consenso e diversidade de significados [The quality of education in Brazil: consensus and diversity of meanings]. (Master Thesis), Universidade de São Paulo, São Paulo.

Gustafsson, B. A., Shi, L., \& Sicular, T. (2008). Inequality and Public Policy in China. New York, NY: Cambridge University Press.

Haddad, S., \& Di Pierro, M. C. (2000). Escolarização de jovens e adultos [Schooling of youngsters and adults]. Revista Brasileira de Educação, 14, 108-130.

Han, M., \& Yang, X. (2001). Educational assessment in China: Lessons from history and future prospects. Assessment in Education: Principles, Policy \& Practice, 8(1), 5-10.

Harris, J., Zhao, Y., \& Caldwell, B. (2009). Global characteristics of school transformation in China. Asia Pacific Journal of Education, 29(4), 413-426.

Higher School of Economics. (2013, August 2). HSE Is Entering BRICS League of Universities. Retrieved from www.hse.ru/en/news/community/90343147.html

Hong, L. (1991). 我国教育督导制度的历史沿革和现状 [The historical course of development and the current state of the Chinese education supervision system]. 北京师范学院 学报(社会科学版), 4, 6-10.

Horta Neto, J. L. (2007). Um olhar retrospectivo sobre a avaliação externa no Brasil: das primeiras medições em educação até ao SAEB de 2005 [A retrospective look at external evaluation in Brazil: From the first measurements in education until SAEB 2005]. Revista Iberoamericana de Educación, 42(5), 1-13.

Huang, W. (2009). 我国教育督导体制现状、问题与改革路径 [The current state, problems and reform path of the Chinese education supervision system]. 教育发展研究, 12, $16-20$.

Huo, C., \& Gao, H. (2006). The new "Compulsory Education Law" and the balanced development of compulsory education in China. 山西高等学校社会科学学报, 18(12), 37-39.

Ianni, O. (1975). A formação do estado populista na América Latina [The formation of the populist state in Latin America]. Rio de Janeiro: Civilização Brasileira.

The Indian Express (2016, 30 September). BRICS Nations Pledge to Step Up Cooperation in Education Sector. Retrieved from http://indianexpress.com/article/education/ brics-nations-pledge-to-step-up-cooperation-in-education-sector-3058246/

Jin, Y. (2004). “督政”与 “督学” 相结合 - 具有中国特色的我国教育督导制度 [Combination of administrative supervision and educational inspection - the characteristic of educational supervisory work in our country]. 徐州师范大学学报 (哲学社会科学版), $30(2), 120-124$.

Kauko, J., Centeno, V. G., Candido, H. H. D., Shiroma, E., \& Klutas, A. (2016). The emergence of quality assessment in Brazilian basic education. European Educational Research Journal, 15(5), 558-579.

Keukeleire, S., \& Hooijmaaijers, B. (2014). The BRICS and other emerging power alliances and multilateral organizations in the Asia-Pacific and the Global South: Challenges for the European Union and its view on multilateralism. Journal of Common Market Studies, 52(3), 582-599.

Kipnis, A. (2006). Suzhi: A keyword approach. The China Quarterly, 186, 295-313. 
Klein, R. (2006). Como está a educação no Brasil? O que fazer? [How is education in Brazil? What to do?]. Ensaio: Avaliação de Políticas Públicas Educacionais, 14(51), 139-172.

Laliberté, A., \& Lanteigne, M. (2008). The issue of challenges to the legitimacy of CCP rule. In A. Laliberte \& M. Lanteigne (Eds.), The Chinese Party-State in the 21st Century: Adaptation and the Reinvention of Legitimacy (pp. 1-21). London \& New York, NY: Routledge.

Law (9.394). LEI No 9.394, de 20 de Dezembro de 1996 [Law number 9,394 from 20 December 1996]. Retrieved November 23, from www.planalto.gov.br/ccivil_03/Leis/L9394.htm

Law, W. (2007). Legislation and educational change: The struggle for social justice and quality in China's compulsory schooling. Education and the Law, 19(3-4), 177-199.

Lee, J., Ding, D., \& Song, H. (2008). School supervision and evaluation in China: The Shanghai perspective. Quality Assurance in Education, 16(2), 148-163.

Lee, T. H. (2000). Education in Traditional China: A History. Leiden, Boston, \& Köln: Brill.

Liu, M. (2016). BRICS development: A long way to a powerful economic club and new international organization. The Pacific Review, 29(3), 443-453.

Liu, Y. (2008). 我国基础教育评价改革的反思与展望 [Reflection and prospect of basic education evaluation reform in China]. 中国民族教育, 9, 10-12.

Livschiz, A. (2006). Pre - revolutionary in form, Soviet in content? Wartime educational reforms and the postwar quest for normality. History of Education, 35(4-5), 541-560.

Long, D., \& Long, R. (1999). Education of Teachers in Russia. Westport: Greenwood Press.

Longo, R. M. J. (1996). Gestão da Qualidade: Evolução Histórica, Conceitos Básicos e Aplicação na Educação [Quality Management: Historical Evolution, Basic Concepts and Its Application to Education], Texto para discussão n.397. Paper presented at the Gestão da Qualidade na Educação: Em Busca da Excelência, Centro de Tecnologia de Gestão Educacional, SENAC - SP.

Luckhurst, J. (2013). Building cooperation between the BRICS and leading industrialized states. Latin American Policy, 4(2), 251-268.

Mahoney, J. (2000). Path dependence in historical sociology. Theory and Society, 29, 507-548.

Mayofis, M. (2015). Predvestiia “ottepeli” v sovetskoi schkol'noi politike pozdnestalinskogo vremeni [Portents of the Khrushchev Thaw in the Soviet school policy of the late-Stalin period]. In I. Kukulin, M. Mayofis, \& P. Safronov (Eds.), Ostrova utopii: Pedagogicheskoe i sotsial'noe proektirovanie poslevoennoi shkoly (1940-1980-e) [Islands of Utopia: Pedagogical and the Social Designing of the Post-War School (1940-1980s)] (pp. 35-106). Moscow: Novoe Literaturnoe Obozrenie.

Meade, B., \& Gershberg, A. I. (2008). Making education reform work for the poor: Accountability and decentralization in Latin America. Journal of Education Policy, 23(3), 299-322.

Meisner, M. J. (1999). Mao's China and After: A History of the People's Republic. New York, NY: Free Press.

Minina, E. (2016). "Quality revolution" in post-Soviet education in Russia: From control to assurance? Journal of Education Policy, 31(6), 1-22.

Moreira, J. R. (1956). Os problemas do Ensino Elementar no Brasil [The problems of elementary education in Brazil]. RBEP, 26(64), 48-59.

Nardi, E. L., Schneider, M. P., \& Rios, M. P. G. (2014). Qualidade na educação básica: ações e estratégias dinamizadoras [Quality in basic education: Motivating actions and strategies]. Educação e Realidade, 39(2), 359-390.

Ngok, K. (2007). Chinese education policy in the context of decentralization and marketization: Evolution and implications. Asia Pacific Education Review, 8(1), 142-157.

OECD. (1998). Review of National Policies for Education: Russian Federation. Paris: OECD.

Oliveira, R. P. de, \& Araujo, G. C. de (2005). Qualidade do ensino: uma nova dimensão da luta pelo direito à educação [Educational quality: A new dimension of the struggle for the right to education]. Revista Brasileira de Educação, 28, 5-23.

Oliveira, R. P. de (2007). Da universalização do ensino fundamental ao desafio da qualidade: uma análise histórica [From the universalization of elementary education to the challenge of education: A historical analysis]. Educação \& Sociedade, 28(100), 661-690. 
Oliveira, R. P. de, \& Santana, W. (Eds.). (2010). Educação e federalismo no Brasil: combater as desigualdades, garantir a diversidade [Education and federalism in Brazil: fighting the inequalities, ensure diversity]. Brasília: UNESCO.

O'Sullivan, D., Manson, S. M., Messina, J. P., \& Crawford, T. W. (2006). Space, place, and complexity science. Environmental Planning A, 38(4), 611-617.Pant, H. V. (2013). The BRICS fallacy. The Washington Quarterly, 36(3), 91-105.

Peixoto, A. M. C. (1995). L'influence des idées étrangères sur l'enseignement au Brésil [The influence of foreign ideas on education in Brazil]. Histoire de l'Education, 65(1), 3-26.

Peng, W., Thomas, S. M., Yang, X., \& Li, J. (2006). Developing school evaluation methods to improve the quality of schooling in China: A pilot 'value added' study. Assessment in Education: Principles, Policy \& Practice, 13(2), 135-154.

Phillips,D. (2017,19 July). “People are getting poorer”:Hunger and homelessness as Brazil crisis deepens. The Guardian.Retrieved from www.theguardian.com/global-development/2017/ jul/19/people-getting-poorer-hunger-homelessness-brazil-crisis

Piattoeva, N., \& Gurova, G. (2018). Domesticating international assessments in Russia: Historical grievances, national values, scientific rationality and education modernization. In C. Alarcón \& M. Lawn (Eds.), Assessment Cultures: Historical Perspectives (pp. 87-110). Frankfurt am Main: Peter Lang.

Pierson, P. (2000a). Increasing returns, path dependence, and the study of politics. American Political Science Review, 94(2), 251-267.

Pierson, P. (2000b). Not just what, but when: Timing and sequence in political processes. Studies in American Political Development, 14(1), 72-92.

Polyzoi, E., \& Dneprov, E. (2011). A framework for understanding dramatic change: Educational transformation in post-Soviet Russia. International Perspectives on Education and Society, 14, 155-179.

Postiglione, G. A. (2011). Education. In X. Zang (Ed.), Understanding Chinese Society (pp. 80-95). London \& New York, NY: Routledge.

$\mathrm{Pu}, \mathrm{X}$. (2012). Socialisation as a two-way process: Emerging powers and the diffusion of international norms. The Chinese Journal of International Politics, 5, 341-367.

Qi, T. (2011). Moving toward decentralization? Changing education governance in China after 1985. In T. Huang \& A. W. Wiseman (Eds.), International Perspectives on Education and Society Book Series, Vol. 15, The Impact and Transformation of Education (pp. 19-41). Bingley: Emerald Group Publishing Limited.

Robinson, B., \& Yi, W. (2008). The role and status of non-governmental (“daike”) teachers in China's rural education. International Journal of Educational Development, 28(1), 35-54.

Romanelli, O. D. O. (2007 [1978]). História da educação no Brasil (1930/1973) [History of Education in Brazill. Petrópolis, Brasil: Editora Vozes.

Schwartzman, S., Pinheiro, R., \& Pillay, P. (Eds.). (2015). Higher Education in the BRICS Countries: Investigating the Pact Between Higher Education and Society. London \& New York, NY: Springer.

Seregny, S. J. (1993). Teachers, politics and the peasant community in Russia, 1895-1918. In School and Society in Tsarist and Soviet Russia (pp. 121-148). London: Palgrave Macmillan.

Sobreira, R., \& Campos, B. C. (2008). Investimento público em educação fundamental e a qualidade do ensino: uma avaliação regional dos resultados do Fundef [Public investment in elementary education and the quality of education: A regional evaluation fo Fundef results] Revista de Administração Pública (RAP), 42(2), 327-246.

Souza, A. M., \& Costa, M. A. (2009). Reformas do ensino básico: tendências e limites [Basic education reforms: Trends and limits]. Ensaio: Avaliação e Políticas Públicas em Educação, 17(64), 477-494.

Souza, C. (2002). Brazil: The prospects of a center-constraining federation in a fragmented polity. Publius, 32(2), 23-48. 
Startsev, B. (2012). Khroniki obrazovatelnoi politiki: 1991-2011 [Chronicles of Educational Policy: 1991-2011]. Moscow: Izdatel'skii dom Vysshei shkoly ekonomiki.

Stuenkel, O. (2014). Emerging powers and status: The case of the first BRICs summit. Asian Perspective, 38, 89-109.

Teets, J. C. (2013). Let many civil societies bloom: The rise of consultative authoritarianism in China. The China Quarterly, 213, 19-38. Tret'iakov, P. (1997). Upravlenie shkoloi po rezul'tatam. Praktika pedagogicheskogo menedzhmenta. [Managing school by results. The practice of pedagogical management]. Moscow: Novaia shkola.

Ünay, S. (2013). Reality or mirage? BRICS and the making of multipolarity in the global political economy. Insight Turkey, 15(3), 77-94.

Vianna, H. M. (1990). Avaliação do rendimento de alunos de escolas de 1.0 grau da rede pública: um estudo em 15 capitais e 24 cidades [Performence Evaluation of 1st Grade Pupils in Public Schools: A Study in 15 Capitals and 24 Cities]. São Paulo: Fundação Carlos Chagas.

Wang, X. (2003). Education in China Since 1976. London: McFarland \& Company.

Wang, Z., \& Zhang, L. (2009). 我国基础教育课程监控机制的构建 - 基于历史分析的视角 [The construction of the Chinese basic education curriculum monitoring mechanism - a historical analysis perspective]. 现代教育管, 8, 61-63.

West, R., \& Crighton, J. (1999). Examination reform in central and Eastern Europe: Issues and trends. Assessment in Education, 6(2), 271-289.

Wirth, J. D. (1997). Reviewed work: The means of our salvation: Public education in Brazil, 1930-1995 by David N. Plank. American Journal of Education, 105(4), 484-488.

World Bank. (1995). Russia: Education in the Transition. Washington, DC: World Bank Publications.

World Bank. (1999). Reforming Education in the Regions of Russia. Washington, DC: World Bank Publications.

World Bank. (2001). Russia - Education Reform Project. Washington, DC: World Bank Publications.

Wu, J., \& Dai, J. (2013). 我国课程监控制度探析 [Probing into the curriculum monitoring system of China]. 教育理论与实践 Theory and Practice of Education, 4, 53-56.

Wu, X. (2012). School choice with Chinese characteristics. Comparative Education, 48(3), 347-366.

Xin, T., \& Kang, C. (2012). Qualitative advances of China's basic education since reform and opening up: A brief overview. Chinese Education and Society, 45(1), 42-50.

Xinhua. (2016, 30 September). 4th BRICS Education Summit held in New Delhi. Retrieved from http://news.xinhuanet.com/english/2016-09/30/c_135726098.htm

Xu, F., \& Li, H. (2011). 基础教育质量标准及评价体系探讨 [An investigation into the system of basic education quality standards and assessment]. 教育与教学研究, 3, 48-50.

Yang, J. (2001). 20年来我国教育督导理论与实践的新探索 [Twenty years of theory and practice in education inspection in China: An exploration]. 西北师大学报(社会科学版), 38(2), 36-42.

Yang, Y., \& Guo, L. (2005). 督政与督学相结合 - 中国教育督导制度的显著特色 [Combination of administrative supervision and educational inspection]. 教育科学, 21(2), 37-40.

Zhang, Z. (2010). 中国基础教育监测的实践与思考 [The practice and exploration of basic education monitoring in China]. 基础教育, 7(7), 3-7.

Zhou, J., \& Reed, L. (2005). Chinese government documents on teacher education since the 1980s. Journal of Education for Teaching, 31(3), 201-213.

Zhou, S. (2012). 国内外基础教育质量监测概览 [An overview of basic education quality monitoring at home and abroad]. 江苏教育研究, 6, 58-63.

Zhu, Y. (2011). "Performance Legitimacy" and China's political adaptation strategy. Journal of Chinese Political Science, 16(2), 123-140. 